\title{
Blend Words and Their Influence on the Lexicon and Future of English Language
}

\author{
Laila Othman Baram ${ }^{1}$, Aram Kamil Noori ${ }^{2}$ \\ ${ }^{1}$ College of Language, University of Sulaimani, Sulaimani, Kurdistan Region, Iraq \\ ${ }^{2}$ English Department, Institute of Training and Educational Development in Sulaimani, Sulaimani, Kurdistan Region, Iraq
}

\begin{abstract}
This research studies the widening range of forming and using blend (portmanteau) words in English language. It sheds light on the fact that most blend words are exocentric not only for second language learners but also to natives too, since they have not been listed in English dictionaries. Even if listed; still the continuous process of forming blend words will leave no room to catch up with listing all of them. English nowadays has become the most dominant language and at the same time it has been influenced by some factors as much as it has been influential. In terms of word formation processes especially blending, one can realize how rapidly and unexpectedly new words are coined for new purposes in accordance with daily life needs. In this era of speed; English native speakers, as their nature, do like to economize in their word choice especially in their word formation processes such as blending, acronyms, clipping and all types of abbreviations. In fact, the inevitability of life change as the result of daily life's needs inventions influences English language in many ways. In addition, the policy of economizing and being selective reflects well on letter choice and word forming processes. In relation to this, the consequences of life change can be noted in studying blend forms in English. Some simple examples are: blunch, chexting, spork, feminar, brinner, brunch, fanzin, hubot, smog, etc. In a nut shell, the research states the inevitable and intriguing change of English words in the process of blending in which two or more words are cut and mixed together to form a new form, called a blend word. One basic point here is that a blend word is not simply one word; brinner as an example is formed from three other words (breakfast + lunch + dinner) to describe a situation in which you just have one meal instead of the three. Most of blend words have not so far been listed in English dictionaries. So this continuous process of forming new words does a great change to English vocabularies now and in the upcoming years.
\end{abstract}

Index terms - blending, lexicon, language change, portmanteau, productivity.

\section{Methodology}

This paper is designed to highlight the process of language change through linguistic innovation and in particular forming new words through the process of blending. It studies blend words in English; the study is exploratory-interpretative, in which blends have been gathered, compared and investigated. Data are collected from books and internet research. Blends are classified under different categories, in terms of both structure and reasons behind coining them. Examples of blends and their source words are stated together elaborating their meaning.

\section{INTRODUCTION}

No doubt that in conjunction with daily life changes, words may be added or lost in every language. Some words may disappear from languages, some others may be added to the lexicon, especially the domain of technological developments is constantly nourishing languages. So, the change is something inevitable, but the point in this paper is that the new words look quite exocentric in their very moment of appearance. As life changes, languages change, and the change can be seen by observing the words. The fast-changing life naturally affects language and in consequence it reflects on the words and the overall system of that language.

As Garg (2005, p. 31) claims, "A language is the soul of its people", this is profoundly illustrated in English, a language which is growing too fast in the world. Through exploring newcoined English words and comparing them; one can find the feature of creativity in English Language. One evidence can be new words, especially blended words which are spreading every moment in social media. In addition, technological development can be regarded as a means through which new expressions are continuously coined and spreading, then through the passage of time they will be lexicalized and become part of the English Lexicon. Consequently, language users become acquainted with the new words and use them as naturally as they use other vocabularies of their language. Definition

Blending has been defined by different linguists in many different ways. Hudson (2000, p. 244) defines it in terms of its relation to other processes of word formation. He compares blending to processes like clipping and acronyms all starting out under the notion abbreviation. The mere difference between blending and the other two is that the former is replacing two words with parts of both, generally the first part of the first and

Journal of University of Human Development

Volume 5 No. 3(2019); DOI: 10.21928/juhd.v5n3y2019.pp43-48

Regular research paper: Published 8 July 2019

Corresponding author's e-mail: laila.othmann@gmail.com

Copyright (C2019 Laila Othman Baram, Aram Kamil Noori. This is an open access article distributed under the Creative Commons Attribution

License (CC BY-NC-ND 4.0) 
the last part of the second. Hudson states that with the passage of time new blends can become natural words in their own right as in the example motel from (motor \& hotel) to refer to any hotel that provides car park or garages for the guests who have cars.

Similarly, Hamawand (2011, p. 11) defines blending as a morphological term stating that "blending is a morphological device by which a new word is coined by parts of two (or more) words", usually the first part of one is combined with the last part of another. English Speakers use the blend smog coined from the two source words smoke and fog to talk about the combined effects of smoke and fog. Generally the new term (the blend) is formed by taking the beginning of one word and joining it to the end of the other word. Another example is gasohol from (gasoline + alcohol) a blend which is formed and used to refer to a product which works as gasoline but is made from alcohol (Hamawand, 2011, p 11).

Yule (2006, p.53,59) defines blending as a process which involves the combination of two separate forms to produce a single new word, via taking only the beginning of one word and joining it to the end of the other word.

Crystal (2003, p.54) Defines it as a process in which two ELEMENTS that do not normally co-occur, according to the RULES of the language, come together within a single LINGUISTIC UNIT (a blend). He also (Crystal, 2006, p. 277) states that blending is a method of joining two shortened forms of two original words together.

Fromkin et. al. (2003, p. 98) and Trask and Milller (2015, p. 29) define blending in comparison to other processes like compounding and clipping as a sort of combination of compounding and clipping, in which pieces of existing words are combined to make a new word and parts of the source words that are combined are deleted, for them some well-known examples are motel ( motor plus hotel), informercial from (information plus commercial), broasted from (boiled Plus roasted), Oxbridge (Oxford plus Cambridge), Miller (2015, p. 29) refers to some more recent coined blends; which include heliport (helicopter plus airport), Eurovision (European plus television), Breathalyzer (breath plus analyzer), and chunnel (Channel plus tunnel). He also states that such formations are beloved by advertisers and journalists to play with words and constantly create new words.

One more definition is by Stranzy (2005, p. 429) who claims that blending is another productive type of word formation, where normally initial and terminal segments of two words are joined together to create a new word, for example, brunch (breakfast + lunch). Recent English examples include selectorate (selectors + electorate), fantabulous (fantastic + fabulous).

In fact blending is not a new word formation process in English language, long time ago words have been coined to form a new one; the term brunch originated in England in the late 19th century and became popular in the United States in the 1930s. Lewis Carrol was the pioneer of blending; he tried to pack two words into one (1872), and was famous for both coining and blending of words. He used blends like gallumph from (gallop + triumph) meaning to walk proudly and victoriously and chortle from (chickle + snort).

The change in English language terminologies continues as life continues. A new blend for the three meals (breakfast +lunch+ dinner) is brinner that describes a situation of having just one meal instead of the three. One more word play in blending is again related to the meals; blunch is a blend from breakfast and lunch when the first meal of day is eaten at lunchtime at about 12 or $1 \mathrm{pm}$ as opposed to brunch which is eaten at 10 or $11 \mathrm{am}$. Also the blend webinar from (web + seminar) an online seminar, has been changed to feminar, when it (the seminar) is limited only to females (feminine+ seminar) (urbandictionary.com).

To sum up, blending, as a productive process of word formation, has a vital role in adding new words to English lexicon, i.e. via coining new words the process participates in enriching the lexicon. Blending is like the other processes of word formation such as initialism, compounding, clipping, acronym etc. but still there are some differences. In blending, new formed words are somehow strange and need identifying and understanding the source words. For instance one simple difference between blending and compounding is that in blending only parts of the words are combined while in compounding the source words are totally combined without omitting any letter (i.e. the source words are retained as they are). Blending is also different from abbreviation, initialism and acronyms in that the resultant word (the blend word) often looks like ordinary words and can be conjugated chext, chexted, chexting and blog, blogger, while in abbreviation the result word is just a combination of isolated (basically initial) letters and may not be conjugated as naturally as other English words.

\section{TYPES OF BLENDS}

As stated above, parts of two or more words are mixed together to form a blend word. But for each type, different parts are taken from the source words i.e. the position of the retained letters or parts are different. Below are some formation rules that can be realized and identified in making up blend words:

1. The beginning of one word is added to the end of the other, in which the sounds and meanings of the two word parts are merged.

For example, brunch is a blend of breakfast and lunch. Globish from (global + English)

smog from (smoke + fog )

Chinglish from (Chines + English)

motel from (motor + hotel )

pictionary from (picture+ Dictionary)

2. The first source word is used in its entirety with the second part of the second word:

friendiversary from ( friend + anniversary)

Gobot from (go+robot) to refer to a robot vehicle glassphalt from (glass+asphalt)

3. The first part of the two words are overlapped as in: sitcom from (situation + comedy)

biopic from (biography+picture)

4. The beginning of one word is added to the beginning of 
another, as in:

Telex from (teleprinter + exchange)

5. The beginning of one word is added to the (whole) of the other source word:

blunch : from ( breakfast and lunch)

email: from (electronic + mail)

vlog: from (video $+\mathbf{l o g}$ )

6. The last letter (or last part) of one source word is added to the (whole) of the other source word

blog from (web + log)

\section{HISTORICAL BACKGROUND}

Nowadays, the study of blended words is essential because English language is evolving so rapidly due to extensive use of technology such that we cannot catch up with the new words produced by native speakers. Blending is one of the methods which speakers manipulate to get quick access to communicating with the people around them.

Blending dates back to Lewis Carroll (1872). He used portmanteau, which is another term for blend, in his book Alice Through the Looking Glass to delineate the nonsense word "Jabberwocky," which starts with:

"Well 'slithy' means 'lithe and slimy' ... you see it's like a portmanteau - there are two meanings packed up into one word."

The blend word 'slithy' is composed of two lexemes 'lithe and slimy' which are completely different from each other in meaning, and consequently a new word is coined 'slithy' whose meaning is derived from both. Portmanteau is an outdated word which refers to "suitcase" which used to be carried on horsebacks. Other examples include flimserable (flimsy + miserable) (Stockwell and Minkova, 2001, p. 6).

Blends have become a typical feature of the English language. We can find numerous examples of blends from every aspect of English such as technology, business, medicine, engineering, etc. Stevenson et at (2007) provide several blend words which existed before Carroll (1872), for example; anecdotage (anecdote + dotage to mean a garrulous old age, from1823); squirl (squiggle+ whirl to explain a flourish especially handwriting, from 1843); snivelization (snivel + civilization to describe civilization considered derisively as a cause of anxiety or plaintiveness, in 1849); squdge (squash + pudge) from 1870.

\section{PRODUCTIVITY}

Human language is, by nature, productive. It can generate countless different sentences without being repeated. This feature marks the difference between human language and animal communication which lacks productivity. Blending is one of the productive tools language users utilize within the process of delivering the message to the receiver. It is productive because there can be found a large number of examples of this word formation process in different languages. There are several strategies to create blend words. For example, blends are created from the first part of both words such as sysop (system + operator), second part of the two words podcasting (ipod + broadcasting), and other blends are created as shown in samples like malware (malicious + software, webzine $(w e b+$ magazine, qubit $=q u a n t u m+b i t)$. These various methods of coining blends show the productivity of the process. There are so many blend words that do not gain entry into the dictionaries due to creating lots of blend words by language users.

Katamba and Stonham (2006, p.74) define the term productivity as a synonym of creativity, stating that "productivity is the capacity of all human language to use finite means to produce an infinite number of words and utterances". He also views productivity in terms of generality: the more general a word-formation process is, the more productive it will be assumed, by stating two plausible key points requiring elucidation:

1. Productivity is a matter of degree i.e. some processes are much more general and more productive than others.

2. Time affects productivity of each process, i.e. productivity degree is subject to change in different periods of time. Stating that "a process which is very general during one historical period may become less so at a subsequent period, conversely, a new process entering a language may initially affect a tiny fraction of eligible inputs before eventually applying more widely". (ibid)

Crystal (2003, p. 54) supports the very fact that blending has a great impact on broadening English language as he states "Blending is a common source of new words, through abbreviation, as interpole and Eurovision" That is, blending is the process that affects lexical construction as much as other word formation processes.

\section{FACTORS BEHIND BLENDING}

There are several factors behind the coining of blend words in the language especially in English:

First, as the proverb displays that "necessity is the mother of invention", over time new tools and materials are invented, where each invention needs a word. English is a flexible language which is continually absorbing new words from the languages around the globe. A large number of the words derived into English are from Greek, Latin and other European languages. With the advent of $20^{\text {th }}$ century, blends became more popular in English language. For example, several restaurants started serving a kind of meal between breakfast and lunch, so the word "brunch" was created to fulfill their needs (Nordquist, 2019, The Blend Trend, para.1).

Second, it is the language user who tends to economize their speech so that they can deliver the messages as briefly and quickly as possible. They want to pack two or more ideas or words into one sensible word in a short period of time. Instead of saying two words to get the message across, one word works perfectly. For instance, smoke and fog are blended and smog is used instead to describe both situations.

Third, the coining of blend words is intentional; the language user deliberately creates blend words. When the blend word is produced, usually the first one is shorter and more frequent than the second such as camcorder (camera + recorder) (Gries, 2006). 
Fourth, Adams (2001, p.139) views that blends are sometimes coined from slips of the tongue or writing quickly i.e. they are produced spontaneously and unconsciously such as distruption (destruction + disruption), sombriety (somberness + sobriety) and fixidity (fixity + rigidity).

\section{THE FUTURE OF ENGLISH}

There is no doubt that evolving English is inevitable. Many aspects of English have tremendously changed syntactically, morphologically, phonologically from the earliest period of time. Blending is one of the processes emerged in the evolution of the language. It could be felt that there is a growing interest to this word formation process among the language users these days. So linguists, currently, have no choice except accepting blending as part of the language features. While some linguists do not accept blending because they think these texts were damaging the language as Crystal (2008, p.9) quotes that the British broadcaster John Humphrys depicted the texters as "Vandals who are doing to our language what Genghis Khan did to his neighbors 800 years ago. They are destroying it: pillaging our punctuation; savaging our sentences; raping our vocabulary. And they must be stopped."

Any change in language, at first, faces resistance before it has become popular among people. The same applies to blends; at first, people think that this is destroying the language, but actually this is the way the language should work. Language evolution does not stand still but it is in a process of change over time.

Blend words have now become a norm since they have spread in every aspect of language. This phenomenon has covered every domain of language use such as media, business, technology, engineering, power, authority, and so on. Nowadays, blend words have become part of our daily routine. For example, Brexit (Britain+ exit), we hear this word every day from the news channels.

\section{CONCLUSION}

In Conclusion, it is found that blending is not only a simple process in the formation of words of English Language. It is one major factor for creating a large number of new words by which lexical changes occur in English expression, and consequently in the whole language. Specifically, words that relate to technological development and the overall invention around the world. In fact such new words are revitalizing any language which bears them so profoundly.

- Blending is an increasingly popular method of coining novel expressions, a rapid process that leaves no room for catching them up by Language users. At the same time, blending can be claimed to be the most complex form of wordplay in word-formation.

- Blending clarifies how the English speakers want to express themselves more briefly. They incline to pack two forms and two different meanings in to one new word.

- Blend words emphasize the feature of open-endedness of English lexical categories (nouns, verbs adjectives, etc.) and leads to language change. Many source words may disappear in future. In other words blending may cause the many hundreds of words, that were once used for different purposes centuries ago, may die and be no longer in use.

- Blending adds to the notion of productivity in English language. It is a non-stop process that may lead to unexpected word results in recent years both in quality and quantity of the coined words. Consequently, it alters a lot in English lexicon.

- Learners always need to update their knowledge about blends, enrich their background knowledge and catch up with the newly formed words. At the same time intensive lectures should be given to English learners in regard to blend words and the way they are created.

\section{REFERENCES}

Adams, V. (2001). Complex words in English. Oxfordshire: Taylor and Franscis.

Carroll, L. (1872). Alice Through the Looking Glass [Ebook].

Crystal, D. (2003). A dictionary of linguistics\& Phonetics (5th ed.). UK: Blackwell Publishing.

Crystal, D (2006). How Language Works. UK.Penguin Group

Crystal, D. (2008). Txting: The Gr8 Db8. Oxford: Oxford University Press.

Fromkin, V., Rodman, R., Hyams, N. (2003). An Introduction to Language (7th ed.). (S. Dalphin, Ed.) USA: Michael Rosenberg.

Garg, A.(2005). Another Word a Day. An all-new romp through some of the most unusual and intriguing words in English. USA.John Wilsey \&Sons, Inc.

Gries, S. (2006). Shouldnt it be breakfunch? A quantitative analysis of blend structure in English. Linguistics, 42(3). doi: 10.1515/ling.2004.021

Hamawand, Z. (2011). Morphology in English. Word Formation in Cognitive Grammar. London: Bloomsbury.

Hudson, G. (2000). Essential Introductory Linguistics. UK: Blackwell Publishers Inc.

Katamba, F. and Stonham, J. (2006). Morphology Modern Linguistics second edition. NY: palgrave Macmillan.

Lems, K., Miller, L., \& Soro, T. (2010). Teaching reading to English language learners: Insights from Linguistics. New York, NY: Guilford Press.

Meyer, C. (2012). Introducing English linguistics. Cambridge: Cambridge University Press.

Minkova, D., \& Stockwell, R. (2001). English words: History and Structure. Cambridge: Cambridge University Press.

Nordquist, R. (2019). What Are Word Blend s? Retrieved from https://www.thoughtco.com/blend-words-1689171

Spencer, A., \& Zwicky, A. (2007). The handbook of morphology. Oxford: Blackwell Publishers.

Stevenson, A., \& Brown, L. (2007). Shorter Oxford English dictionary. [Oxford]: Oxford University Press.

Stranzy, P. (2005). Encyclopedia of Linguistics. Tailor \& Frances. London.

Trask, R., \& Millar, R. (2015). Trask's historical linguistics. London: Routledge, Taylor \& Francis Group.

Urban Dictionary. (2019). Retrieved from https://www.urbandictionary.com/

Wikipedia. (2019). Retrieved from https://www.wikipedia.org/

Yule, G. (2006). The Study of Language. Cambridge: Cambridge University Press. 


\section{APPENDIX}

List of blend words (extracted from Wikipedia): Animal

- beefalo, from beef and buffalo

- cameleopard, from camel and leopard

- $\quad$ donkra, from donkey and zebra

- geep, from goat and sheep

- $\quad$ hebra, from horse and zebra

- $\quad$ liger, from lion and tiger

- $\quad$ sheeple, from sheep and people

- $\quad$ squitten, from squirrel and kitten

- wholphin, from whale and dolphin

- $\quad$ zedonk, from zebra and donkey

Transport

- $\quad$ boatercycle, from boat and motorcycle

- $\quad$ Jeepster, from Jeep and roadster

- $\quad$ moped, from motor and pedal

- $\quad$ motorcade, from motor and cavalcade

- $\quad$ motorcycle, from motorized and bicycle

- $\quad$ taxicab, from taximeter and cabriolet

- $\quad$ toppo, from top and the Japanese word noppo

- $\quad$ venza, from venture and monza

Cuisine

- $\quad$ alcopop, from alcohol and pop

- banoffee, from banana and toffee

- broccoflower, from broccoli and cauliflower

- $\quad$ brunch, from breakfast and lunch

- cheeseburger, from cheese and hamburger

- $\quad$ chork, from chopsticks and fork

- $\quad$ cronut, from croissant and doughnut

- $\quad$ flavorite, from flavor and favorite

- $\quad$ froyo, from frozen and yogurt

- $\quad$ Funyuns, from fun and onions

- gastropub, from gastronomy and public house

- $\quad$ knork, from knife and fork

- $\quad$ mocktail, from mock and cocktail

- $\quad$ peacherine, from peach and nectarine

- $\quad$ peacotum, from peach, apricot and plum

- $\quad$ pineberry, from pineapple and strawberry

- $\quad$ scotchka, from scotch and vodka

- $\quad$ spife, from spoon and knife

- $\quad$ sporf, from spoon, fork and knife

- $\quad$ spork, from spoon and fork

- $\quad \underline{\text { tangelo, }}$, from tangerine and pomelo

- $\quad$ tofurkey, from tofu and turkey

- $\quad$ tomacco, from tomato and tobacco

\section{Internet and computing}

- $\quad$ bitmoji, from bit and emoji

- $\quad$ blog, from web and log

- blogosphere, from blog and atmosphere

- $\quad$ codec, from coder and decoder

- $\quad$ datacasting, from data and broadcasting

- $\quad$ email, from electronic and mail

- emoticon, from emotion and icon

- favicon, from favourite and icon
- folksonomy, from folk and taxonomy

- $\quad$ freemium, from free and premium

- freeware, from free and software

- Intellivision, from intelligent and television

- $\quad$ Internet, from international and network

- Linux, from Linus and Unix

- malware, from malicious and software

- $\quad$ modem, from modulator and demodulator

- $\quad$ phablet, from phone and tablet

- $\quad$ pixel, from picture and element

- $\quad$ podcast, from iPod and broadcast

- $\quad$ screenshot, from screen and snapshot

- $\quad$ sysop, from system and operator

- $\quad$ log, from video and blog

- $\quad$ webcast, from World Wide Web and broadcast

- webinar, from World Wide Web and seminar

- webisode, from World Wide Web and episode

- Wikipedia, from wiki and encyclopedia

- Wintel, from Windows and Intel

Marketing

- $\quad$ advertainment, from advertising and entertainment

- advertorial, from advertising and editorial

- $\quad$ cineplex, from cinema and complex (building)

- confusopoly, from confusion and monopoly or oligopoly

- $\quad$ multiplex, from multiple and complex - this word has a different meaning in telecommunications

- petrodollar, from petroleum and dollar

- telemarketing, from telephone and marketing Organizations and companies

- Accenture, from accent and future (accent on the future)

- $\quad$ Amtrak, from American and track

- $\quad$ Comcast, from communication and broadcast

- $\quad$ Compaq, from compatibility and quality

- ConEd, from Consolidated and (Thomas) Edison; a large electric utility in the New York metropolitan area

- $\quad$ Conservapedia, from conservative and Wikipedia

- $\quad$ Copa, from compania and Panamena

- $\quad$ Creamsicle, from cream and popsicle

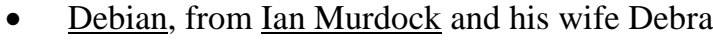

- $\quad$ Digitas, from Digital and Veritas

- Edexcel, from educational and excellence

- Extell, from excellence and intelligence

- $\quad$ Fluidrive, from fluid and drive

- $\quad$ Fudgsicle, from fudge and popsicle

- Funimation, from fun and animation

- Garmin, from Gary_Burrell and Min Kao

- Groupon, from group and coupon

- Intel, from integrated and electronics

- Interpol, from International Police (in full, The International Criminal Police Commission), founded 1923 with headquarters in Paris.

- $\quad$ LATAM, from Lan Airlines and TAM Airlines

- $\quad$ Lenovo, from legend and "novo" (Latin ablative for "new")

- $\quad$ Mattel, from Harold "Matt" Matson and Elliot Handler 
- Medi-Cal, California's name for their Medicaid program, from medical and California

- $\quad$ Medicaid, from medicine/medical and aid

- $\quad$ Medicare, from medicine/medical and care

- $\quad$ Microsoft, from microcomputer and software

- $\quad$ Mitel, from Michael Cowpland and Terry Matthews and Lawnmowers after the company's original business plan

- $\quad$ Netflix, from internet and flicks (slang for movie)

- Nikon, from Nippon Kōgaku and Ikon

- $\quad$ Pinterest, from pin and interest

- $\quad$ Prevacid, from prevent and acid

- Qualcomm, from Quality and Communications

- $\quad$ Sony, from sonus (Latin for sound) and sonny (slang for youngster)

- $\quad$ Toshiba, from Shibaura Seisaku-sho and Tokyo Denki through the merger of Tokyo Shibaura Electric K.K.

- $\quad$ Travelocity, from travel and velocity

- $\quad$ Triscuit, from triple (three ingredients) and biscuit

- $\quad$ Ultrabook, from ultraportable and notebook

- Wikimedia, from Wikipedia and media

- $\quad$ Wikipedia, from wiki and encyclopedia

- $\quad$ Yosicle, from yogurt and popsicle

Places

- AfPak, from Afghanistan and Pakistan

- $\quad$ Afro-Eurasia, from Africa, Europe, and Asia

- Autopia, attraction in Disneyland, from automobile and utopia

- Benelux, from Belgium, the Netherlands, and Luxembourg

- $\quad$ BosWash, from Boston and Washington, D.C.

- $\quad$ Brockton, from Brant, Greenock and Walkerton

- $\quad$ Calexico, from California and Mexico

- Calistoga, from California and Saratoga

- $\quad$ Canwood, from Canadian and woodlands

- Chambana, from Champaign and Urbana

- Chiberia, from Chicago and Siberia

- $\quad$ Chindia, from China and India

- $\quad$ Chiraq, from Chicago and Iraq

- $\quad$ Clerval, from claire vallée, French for "clear valley"

- $\quad$ Cotai, from Coloane and Taipa

- Dalworthington Gardens a city in north Texas, from Dallas, Fort Worth, and Arlington

- Delmarva, from Delaware, Maryland, and Virginia

- Delran Township, from the Delaware River and Rancocas Creek

- Donora, from William Donner and Nora Mellon

- Dowisetrepla, from Downwind of the Sewage Treatment Plant (from How I Met Your Mother, a television sitcom)

- $\quad$ Eurasia, from Europe and Asia

- NYLON, from New York City and London
- $\quad$ Nylonkong, from New York City, London, and Hong Kong

- $\quad$ Pennsyltucky, from Pennsylvania and Kentucky

- $\quad$ The Tridge, from Tri-Cities and bridge

- $\quad$ Valsetz, from the Valley and Siletz Railroad, now a ghost town

- WaKeeney, from Warren, Keeney, \& Co.

- Willowick, from Willoughby and Wickliffe, $\mathrm{OH}$

- $\quad$ Woolaroc, from woods, lakes and rocks

Sciences

- $\quad$ abzyme, from antibody and enzyme

- $\quad$ bionics, from biology and electronics

- botox, from botulism and toxin

- $\quad$ caplet, from capsule and tablet

- chemokine, from chemotactic and cytokine

- contrail, from condensation and trail

- $\quad$ cultivar, from cultivated and variety

- $\quad$ cyborg, from cybernetic and organism

- $\quad$ diabesity, from diabetes and obesity

- $\quad$ endorphin, from endogenous and morphine

- $\quad$ EpiPen, from epinephrine and penetrator

- genome, from gene and chromosome

- $\quad$ stiction, from static and friction

- vitamin, from vita and amine

- $\quad$ vocoder, from voice encoder

- $\quad$ wavicle, from wave and particle

Sports and fitness

- $\quad$ BoxRec, from boxing and records

- Deaflympics, from deaf and Olympics

- Mobot, from Mo (Farah) and robot

- Motocross, from motorcycle and cross country

- Monzanapolis, from Monza and Indianapolis

- $\quad$ Paralympics, from parallel (originally paraplegic) and Olympics

- plogging, from "plocka" (Swedish "pick up") and jogging

- Supercross, from "Super Bowl of Motocross"

- $\quad$ wallyball, from wall and volleyball 